$124.0179 \quad$ DR $30 / 6$

RFP-2787

RFP-2787

July 27, 1979

July 27,1979

\title{
A METHOD OF INSPECTING RASCHIG RINGS BY NEUTRON ABSORPTION COUNTING
}

Ronald N. Morris

Richard L. Murri

Merril W. Hume

\author{
Plant Support Laboratory \\ ANALYTICAL LABORATORIES \\ Environmental Analysis and Control \\ ENVIRONMENTAL SCIENCES \\ Instrumentation and Statistical Systems \\ CHEMISTRY RESEARCH AND DEVELOPMENT
}

\section{Rockwell International}

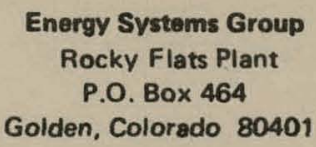

Golden, Colorado 80401

U. S. DEPARTMENT OF ENERGY CONTRACT DE-ACO4-76DPO3533 


\section{DISCLAIMER}

This report was prepared as an account of work sponsored by an agency of the United States Government. Neither the United States Government nor any agency Thereof, nor any of their employees, makes any warranty, express or implied, or assumes any legal liability or responsibility for the accuracy, completeness, or usefulness of any information, apparatus, product, or process disclosed, or represents that its use would not infringe privately owned rights. Reference herein to any specific commercial product, process, or service by trade name, trademark, manufacturer, or otherwise does not necessarily constitute or imply its endorsement, recommendation, or favoring by the United States Government or any agency thereof. The views and opinions of authors expressed herein do not necessarily state or reflect those of the United States Government or any agency thereof. 


\section{DISCLAIMER}

Portions of this document may be illegible in electronic image products. Images are produced from the best available original document. 


\section{-LEGAL NOTICE}

This report was prepared as an account of work sponsored by the United States Government. Neither the United States nor the Department of

Energy, nor any of their employees, nor any of their contractors, subcontractors, or their employees, makes any warranty, expiessed or implied, or assumes any legal liability or responsibility for the accuracy, completenesss or usefulness of any information, apparatus, product or process disclosed, or represents that its use would not infringe privately owned rights.

Printed in the United States of America Available from the National Technical Information Service U. S. Department of Commerce Springfield, Virginia 22161

Price: Printed Copy $\$ 5.00$ Microfiche $\$ 3.00$

Price Is Subject to Change Without Notice 
Printed

July 27, 1979
RFP-2787

UC-23 RADIOISOTOPE AND RADIATION APPLICATIONS

TID-4500-R66

\title{
A METHOD OF INSPECTING RASCHIG RINGS BY NEUTRON ABSORPTION COUNTING
}

Ronald N. Morris

Richard L: Murri

Merril W. Hume

Plant Support Laboratory ANALYTICAL LABORATORIES

Envirommental Analysis and Control ENVIRONMENTAL SCIENCES

Instrumentation and Statistical Systems CHEMISTRY RESEARCH AND DEVELOPMENT

\author{
ROCKWELL INTERNATIONAL \\ ENERGY SYSTEMS GROUP \\ ROCKY FLATS PLANT \\ P.O. BOX 464 \\ GOLDEN, COLORADO 80401 \\ Prepared under Contract DE-AC04-76DPO3533 \\ for the \\ Albuquerque Operations Office \\ U.S. Department of Energy
}

SUBJECT DESCRIPTORS

Raschig Rings

Neutron Detection

Counting Techniques

Neutron Capture

Boron

Quantitative Chemical Analysis

Quality Control

Nuclear Poisons

This report was prepared as an secount of work sponsored by the United States Govermment. Neither the United States nor the United States Department of Energy. nor any of their employees, nor any of their contractors, subcontractors, of their employees, makes any warranty, express or implied, or assumes any legal liability or responsibility for the accuracy, completeness or usefulness of any information, apparatus, product or process disclosed, or represents that its use would not infringe privately owned rights. 
RFP-2787 


\section{CONTENTS}

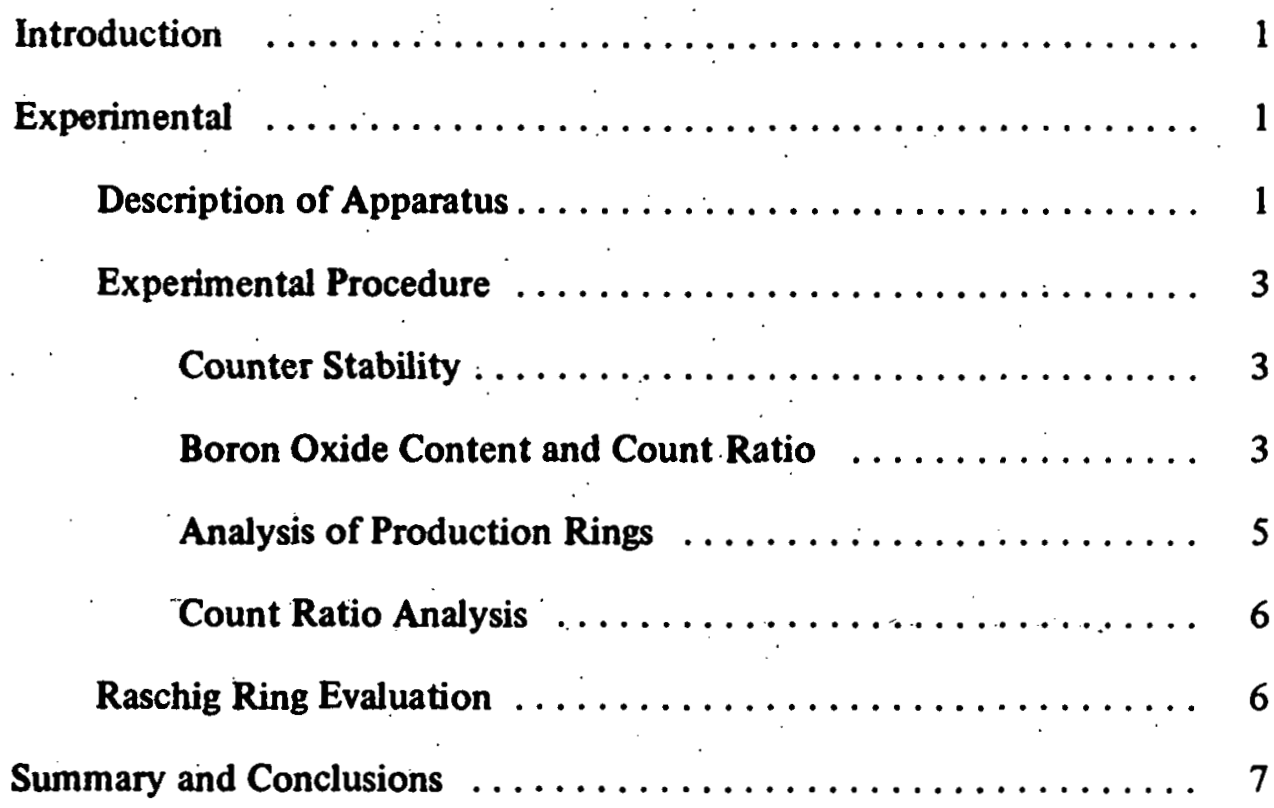


RFP-2787 


\title{
A METHOD OF INSPECTING RASCHIG RINGS
}

\section{BY NEUTRON ABSORPTION COUNTING}

\author{
Ronald N. Morris, Richard L. Murri, and Merril W. Hume
}

\begin{abstract}
A neutron counting method for inspecting borosilicate glass Raschig rings and an apparatus designed specifically for this method are discussed. The neutron count ratios for rings of a given thickness show a linear correlation to the boron oxide content of the rings. The count ratio also has a linear relationship to the thickness of rings of a given boron oxide content. Consequently, the experimentally-determined count ratio and physically-measured thickness of Raschig rings can be used to statistically predict their boron oxide content and determine whether or not they meet quality control acceptance criteria.
\end{abstract}

\section{INTRODUCTION}

Borosilicate glass Raschig rings are used at the Rocky Flats Plant and elsewhere as a means of primary and secondary criticality control. In addition to occupying approximately 30 percent of the volume in a fissile solution tank, the boron in the glass has a relatively high cross section for thermal neutron absorption and thus acts as a sink for thermal neutrons. This prevents a criticality occurrence, since neutrons which could perpetuate a chain reaction are absorbed.

Becuase of the importance of Raschig rings in maintaining nuclear safety, there are certain rigid specifications that must be met. ${ }^{1}$ These include dimensions, boron oxide $\left(\mathrm{B}_{2} \mathrm{O}_{3}\right)$ content, ${ }^{10} \mathrm{~B} /{ }^{11} \mathrm{~B}$ ratio, mechanical strength, and chemical reactivity. The two specifications of interest for the Raschig ring application are $\mathrm{B}_{2} \mathrm{O}_{3}$ content, which must be between 11.8 and 13.8 percent, and the ${ }^{10} \mathrm{~B} /{ }^{11} \mathrm{~B}$ isotopic ratio, which cannot be less than 0.24 . The Raschig rings are manufactured from natural boron which has an isotopic ratio of about 0.24 .

\footnotetext{
${ }^{1}$ Nuclear Safety Standard Number SX-106, "Standard for Borosilicate Glass Raschig Rings for Nuclear Poison." April 29, 1974 revision. Rocky Flats Plant, Rockwell International, Golden, Colorado 80401 .
}

However, it is the ${ }^{10} \mathrm{~B}$ isotope that is effective in absorbing neutrons. The above specifications, taken together, require that the ${ }^{10} \mathrm{~B}$ content be between 0.73 and 0.85 percent, which is sufficient to absorb enough neutrons to be effective as a nuclear poison.

Tests are conducted on new rings as they arrive on plant site and a periodic sampling schedule has been established on rings already in use. Previous testing methods involve fusing the glass sample, then dissolving it, and using atomic absorption for $\mathrm{B}_{2} \mathrm{O}_{3}$ analysis and mass spectrometry for the isotopic ratio. The total time required is about 20 hours for a 3-ring composite sample. The testing method proposed in this paper uses nondestructive neutron counting techniques to directly measure the absorption of neutrons in the Raschig ring. Measurements can be made in about 2 to 3 minutes per ring.

\section{EXPERIMENTAL}

\section{Description of Apparatus}

The counting apparatus consists of a 0.5 -inch diameter boron trifluoride gas proportional counter and a plutonium-beryllium neutron source embedded in a polyethylene moderator. A power supply, preamplifier, amplifier, discriminator, counter, and timer complete the electronic instrumentation. Two such counters have been designed and built. The first uses a single neutron source of approximately $1 \times 10^{6}$ neutrons per second. The second uses two sources of approximately $5 \times 10^{5}$ neutrons per second. Except for the sources, the two designs are identical in their physical dimensions. The double source counter is shown in Figure 1.

The basic design of the apparatus is adapted from DeFord and Barman. ${ }^{2}$ The detector is placed in

\footnotetext{
${ }^{2}$ D. D. DeFord and R. S. Barman. Study of Neutron Absorptiometry and Its Application to the Determination of Boron. Analytical Chemistry 30:1765 (1958).
} 


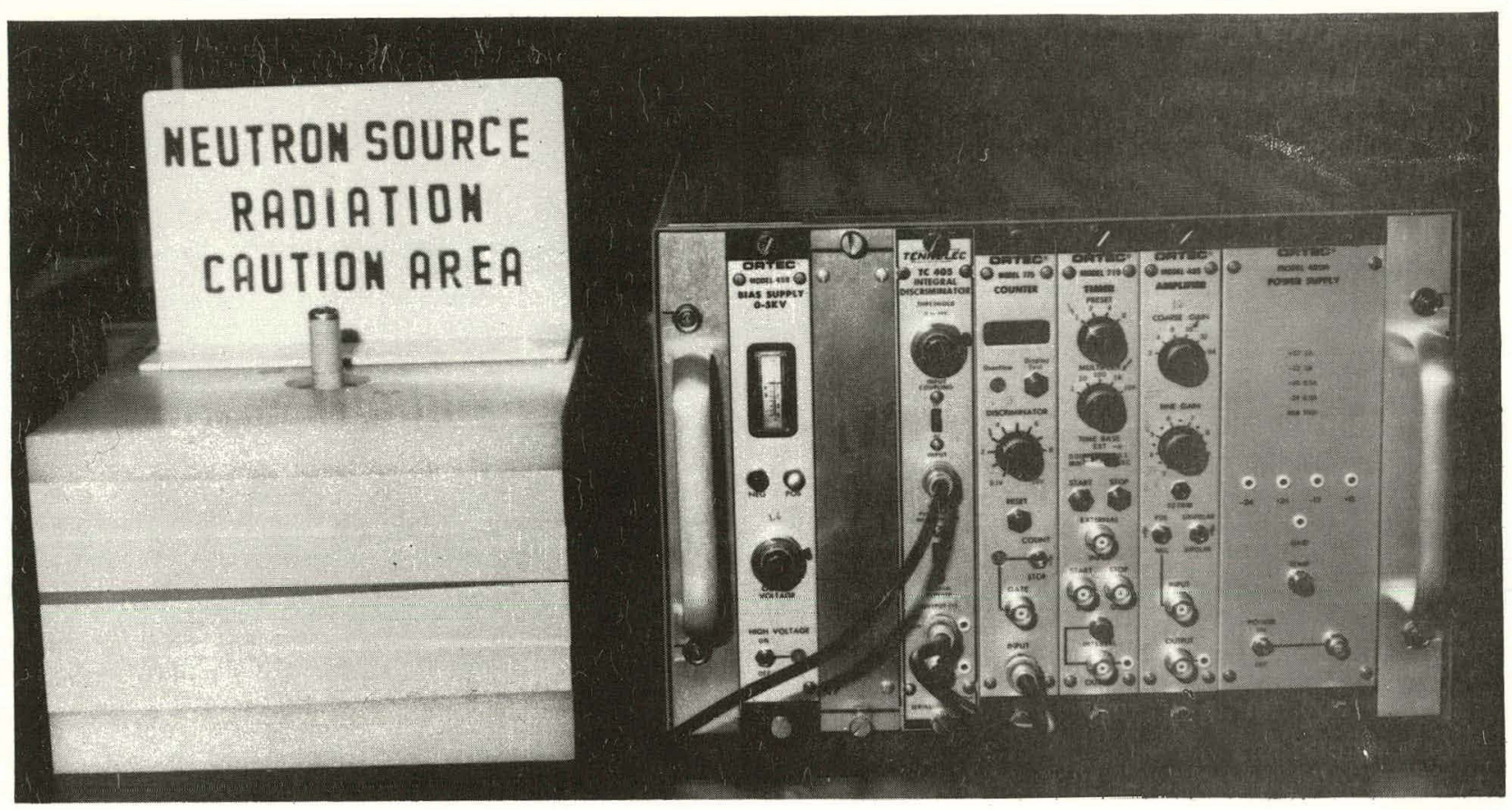

FIGURE 1. Neutron Absorption Apparatus

19679-3

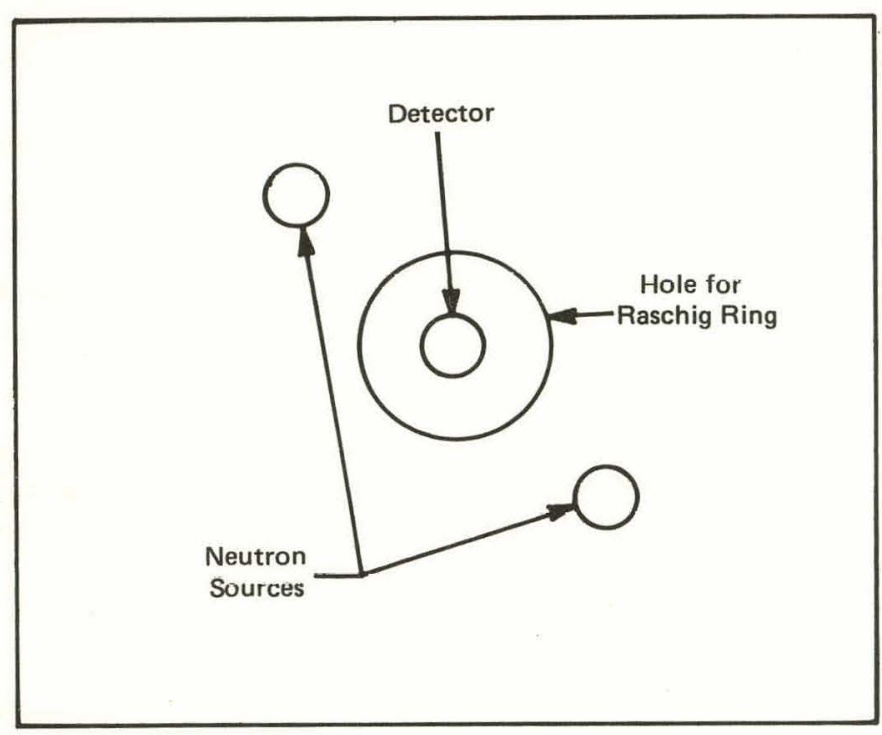

FIGURE 2. Top View of Neutron Counter

the center of the moderator. The Raschig ring to be tested fits into a hole in the moderator such that the detector is also in the center of the ring. The two neutron sources are placed opposite each other on the outside of the Raschig ring. The arrangement is such that neutrons are moderated prior to passing through the ring to the detector. A top view of this arrangement is shown in Figure 2.

A cadmium sleeve is used above and below the detector window to insurc that the detector counts only neutrons that have passed through the volume occupied by the Raschig ring. Neutrons not passing through the glass volume, that are detected, add to the background and are undesirable. Of course, it is impossible to completely eliminate stray ncutrons, but the cadmium sleeves minimize their effect. This arrangement is depicted in Figure 3.

Several parameters were varied in an attempt to optimize the design. These included the size of the moderator, the vertical and radial positions of the neutron sources, the positions of the cadmium sleeves, the placement of polyethylene inside the ring surrounding the detector, and the use of cadmium and borated polyethylene to surround the moderator. The principal criterion used to obtain the best design was a high counting ratio of source count to ring count. The source count was a background count taken without any ring in the 


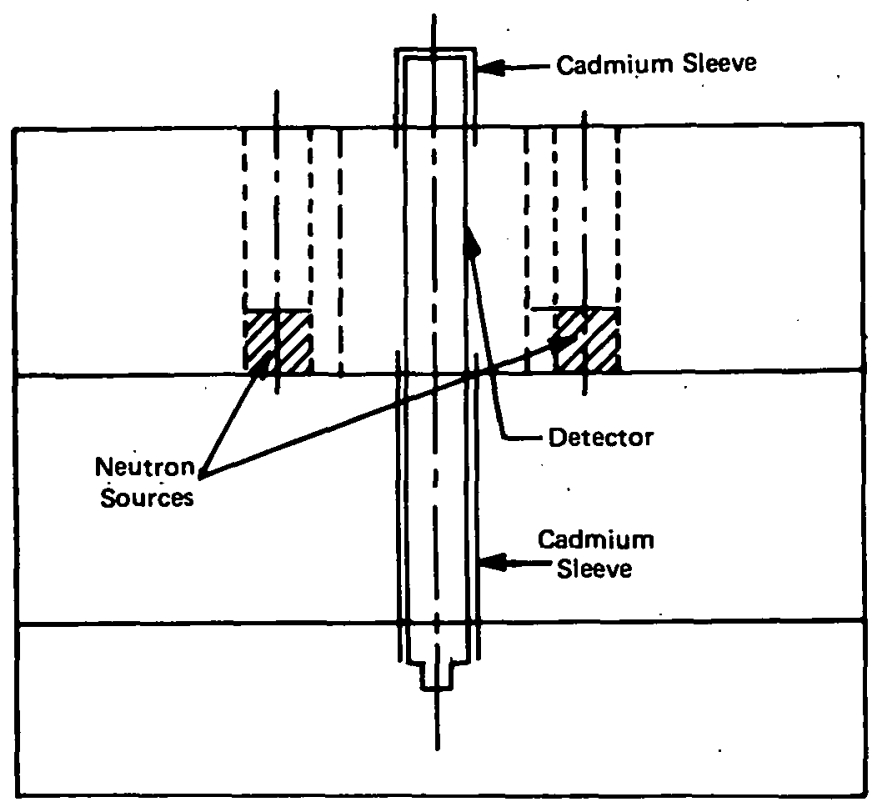

FIGURE 3. Side V iew of Neutron Col!nter

counter. The maximum value of this ratio was realized with the present design.

\section{Experimental Procedure}

Evaluation of Raschig rings involves taking a background or source count, which is essentially the count obtained without any ring in the counter. After determining the source count, a ring is placed in the counter and a sample count taken. These counts are taken for 100 seconds, and the ratio of source count to the ring count is the basic measurement used to correlate boron oxide contents of Raschig rings of known thicknesses. In actual practice, the source count remains sufficiently constant so that only one source count for every ten ring counts is necessary.

Data presented in this report were obtained using the single source counter. Since results of similar. analyses were obtained on the double source counter, numerical inclusions would be redundant.

\section{Counter Stability}

As a check on the counter stability, a standard production ring labeled 5-12 was counted after each source count. The following results were obtained for 56 source and ring 5-12 counts collected over a period of several months. Source count: mean = 34,296 , standard deviation $=173$; ring 5-12 count: mean $=4,362$, standard deviation $=78$; and count ratio: mean $=7.87$, standard deviation $=0.14$.

\section{Boron Oxide Content and Count Ratio}

In order to establish the relationship between boron oxide content and count ratio, an attempt was made to obtain a series of Raschig rings that were identical dimensionally but which contained concentrations of $\mathrm{B}_{2} \mathrm{O}_{3}$ varying from 0.0 to 25.0 weight percent. Unfortunately, the cost of such rings would be prohibitive, since to produce them would require the manufacturer's full production process.

As an alternative, nine rings blown by hand and containing varying $\mathrm{B}_{2} \mathrm{O}_{3}$ contents from about 1.7 to 20 weight percent were selected. These rings were not uniform in wall thickness or diameter based on ten measurements with a micrometer taken while the rings were rotated 360 degrees in a circular manner. The $\mathrm{B}_{2} \mathrm{O}_{3}$ contents of these rings were also in question, because the results of analyses performed by the manufacturer (The Corning Glass Company) and the Rocky Flats Analytical Laboratories deviated from the fabricated (calculated) values. The analysis results of the Corning Glass Company and those obtained from duplicate analyses at Rocky Flats are summarized in Table 1. Ten count ratios were determined for each of these nine rings, with each ring count taken at a different orientation in order to minimize the effects of irregularities in thickness. The relative standard deviations of these count ratios ranged from 1.2 to 4.8 percent which compared favorably with the 1.8 percent relative standard deviation of the count ratio obtained in the 5-12 counter stability study discussed earlier. The standard deviations encountered in the count ratio determinations were significantly better than the variations of the duplicate analyses for $\mathrm{B}_{2} \mathrm{O}_{3}$ performed at Rocky Flats or the agreement between $\mathrm{B}_{2} \mathrm{O}_{3}$ results obtained by Corning and Rocky Flats laboratories.

The least squares plot of count ratio against percent boron oxide determined by Rocky Flats analysis is 
RFP-2787

TABLE 1. Boron Oxide Contents (Weight Percent $\mathrm{B}_{2} \mathrm{O}_{3}$ ) and Mean Count Ratios of a Scries of Hand-Blown Rcference Raschig Rings

\begin{tabular}{|c|c|c|c|}
\hline Calculated as Fabricated & Corning & Rocky Flats Plant ${ }^{\mathrm{a}}$ & $\begin{array}{c}\text { Mean Count Ratio } \\
\text { (95\% Confidence Interval) }\end{array}$ \\
\hline 1.0 & 1.00 & 1.70 & $1.58 \pm 0.07$ \\
\hline 5.0 & 4.76 & 5.61 & $3.63 \pm 0.09$ \\
\hline 10.0 & 9.54 & 9.92 & $6.51 \pm 0.22$ \\
\hline 11.0 & 10.51 & 10.73 & $7.11 \pm 0.46$ \\
\hline 12.0 & 11.61 & 11.90 & $8.23 \pm 0.33$ \\
\hline 14.0 & 13.67 & 14.12 & $10.02 \pm 0.83$ \\
\hline 15.0 & 14.77 & 14.42 & $9.35 \pm 0.35$ \\
\hline 16.0 & 15.95 & 15.32 & $10.21 \pm 0.26$ \\
\hline 23.0 & 22.32 & 30.37 & $14.54 \pm 1.40$ \\
\hline
\end{tabular}

a. Mean result of duplicate analyses.

b. Results based on ten analyses.

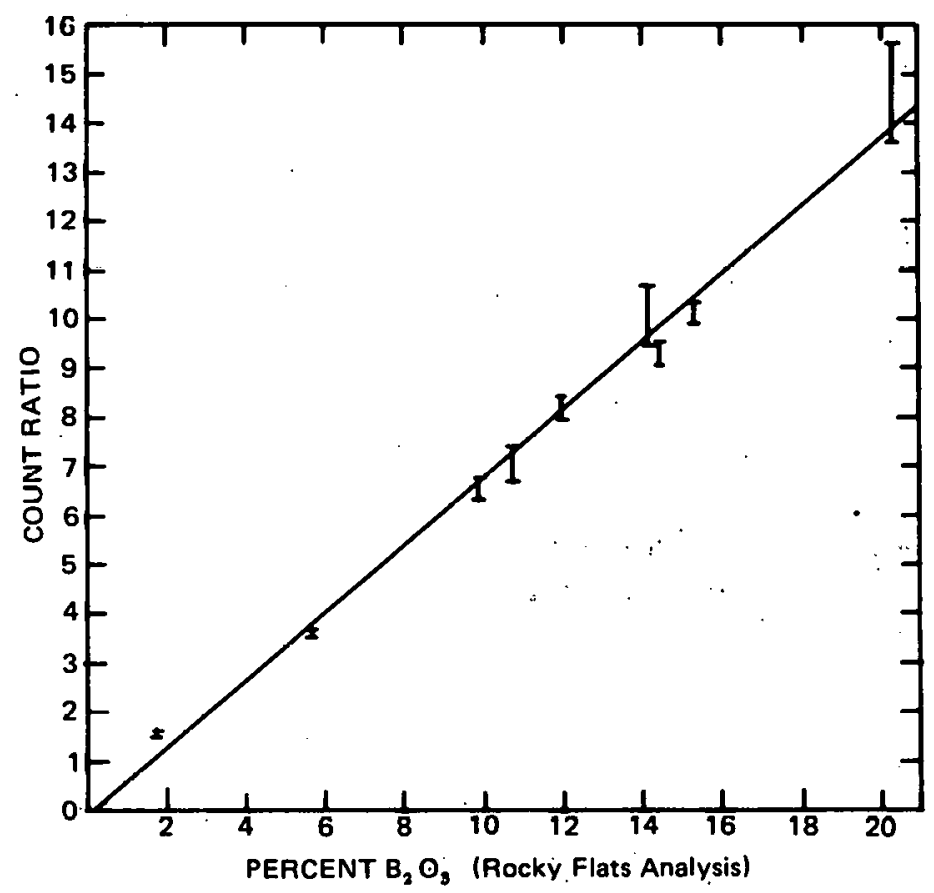

FIGURE 4. Linear Relationship Between Count Ratio and Boron Oxide Concentration

presented in Figure 4. The linear fit is good, as the correlation coefficient is $r=0.995$. The vertical bars cover the range of ten count ratios at each $\mathrm{B}_{2} \mathrm{O}_{3}$ value. In the acceptable $\mathrm{B}_{2} \mathrm{O}_{3}$ range of $11: 8$ to 13.8 weight percent, Nuclear Safety Standard Number
SX-106, the count ratio ranges from 8.1 to 9.5 . However, these values should not be taken as an absolute count ratio range because of the irregular thicknesses and the large variances in the chemical analyses for percent $\mathrm{B}_{2} \mathrm{O}_{3}$ contents of the rings 
TABLE 2. Physical Measurements and Results of Boron Analyses on Three Samples From Each Series of Production Raschig Rings

\begin{tabular}{|c|c|c|c|c|c|c|c|}
\hline $\begin{array}{l}\text { Sample } \\
\text { Number }\end{array}$ & $\begin{array}{l}\text { Length } \\
\text { (inches) }\end{array}$ & $\begin{array}{c}\text { Diameter } \\
\text { (inches) }\end{array}$ & $\begin{array}{l}\text { Thickness } \\
\text { (inches) }\end{array}$ & $\begin{array}{l}\text { Weight } \\
\text { (grams) }\end{array}$ & Mean Count Ratio & $\begin{array}{c}\text { Mean }{ }^{10} \mathrm{~B} /{ }^{11} \text { B Ratio } \\
\text { (95\% Confidence Interval) }\end{array}$ & $\begin{array}{c}\text { Mean } \mathrm{B}_{2} \mathrm{O}_{3} \text { Content } \\
\text { (weight percent) }\end{array}$ \\
\hline $0-1$ & 1.75 & 1.48 & 0.276 & 65.4 & 10.14 & $0.259 \pm 0.001$ & 12.3 \\
\hline $0-2$ & 1.76 & 1.45 & 0.259 & 61.7 & 9.41 & $0.256 \pm 0.006$ & 12.4 \\
\hline 0.3 & 1.75 & 1.44 & 0.253 & 60.8 & 9.00 & $0.250 \pm 0.006$ & .12 .8 \\
\hline P-1 & 1.75 & 1.44 & 0.263 & 62.9 & 9.66 & $0.251 \pm 0.007$ & 12.0 \\
\hline $\mathbf{P}-2$ & 1.76 & 1.46 & 0.262 & 63.6 & 9.64 & $0.255 \pm 0.005$ & 12.5 \\
\hline P-3 & 1.74 & 1.48 & 0.269 & 62.3 & 9.42 & $0.261 \pm 0.002$ & 12.4 \\
\hline Q-1 & 1.73 & 1.44 & 0.254 & 60.9 & 9.13 & $0.261 \pm 0.003$ & 12.6 \\
\hline Q-2 & 1.75 & 1.45 & 0.257 & 61.4 & 9.22 & $0.260 \pm 0.002$ & 12.8 \\
\hline Q-3 & 1.74 & 1.45 & 0.258 & 61.4 & 9.05 & $0.259 \pm 0.003$ & 12.6 \\
\hline $129-1$ & 1.71 & 1.48 & 0.236 & 57.5 & 8.21 & $0.261 \pm 0.004$ & 12.3 \\
\hline $129-2$ & 1.69 & 1.46 & 0.237 & 56.5 & 8.04 & $0.261 \pm 0.005$ & 12.4 \\
\hline $129-3$ & 1.72 & 1.48 & 0.241 & 57.8 & 8.21 & $0.248 \pm 0.007$ & 12.7 \\
\hline $130-1$ & 1.69 & 1.46 & 0.240 & 56.2 & 8.24 & $0.249 \pm 0.006$ & 12.5 \\
\hline $130-2$ & 1.69 & 1.48 & 0.235 & 56.4 & 7.98 & $0.250 \pm 0.007$ & 13.4 \\
\hline $130-3$ & 1.68 & 1.49 & 0.243 & 56.3 & 8.35 & $0.255 \pm 0.000$ & 13.1 \\
\hline
\end{tabular}

counted. A similar range based on count ratio versus percent $\mathrm{B}_{2} \mathrm{O}_{3}$, using the Corning analyses results, would be slightly lower. It should also be noted that the data in Table 1 and Figure 4 are not normalized to the same thickness. If this were to be done, the data in the region of 14 and 16 percent $\mathrm{B}_{2} \mathrm{O}_{3}$ would smooth out and a better fit would be obtained.

\section{Analysis of Production Rings}

As lots of Raschig rings arrive on plant site, they are sampled and tested according to an established quality control procedure of the Health, Safety, and Environmental Group. ${ }^{3}$ Five standard lots labeled $\mathrm{O}, \mathrm{P}, \mathrm{Q}, 129$, and 130 were tested and found

\footnotetext{
${ }^{9}$ Edward A. Putzjer. Private Communication. Rocky Flats Plant. June 1976.
}

to be acceptable by quality control criteria. Three rings from each lot were analyzed for percent $\mathrm{B}_{2} \mathrm{O}_{3}$ and boron isotopic ratio and were also counted by neutron absorption techniques. These results and physical measurements of the rings are presented in Table 2. The pronounced fluctuation in ring thickness, particularly between lots, should be considered since the counter physics is thickness dependent. The least squares plot of count ratio versus ring thickness in Figure 5 shows this dependency.

With an appropriate adjustment for ring thickness, count ratio should serve as a suitable measure of $\mathrm{B}_{2} \mathrm{O}_{3}$ content. The ensuing development of acceptable count ratio limits assumes that the lots analyzed do not differ significantly in $\mathrm{B}_{2} \mathrm{O}_{3}$ content. This conjecture is not in conflict with the data of Table 2 and is strengthened by the Corning certification values. 


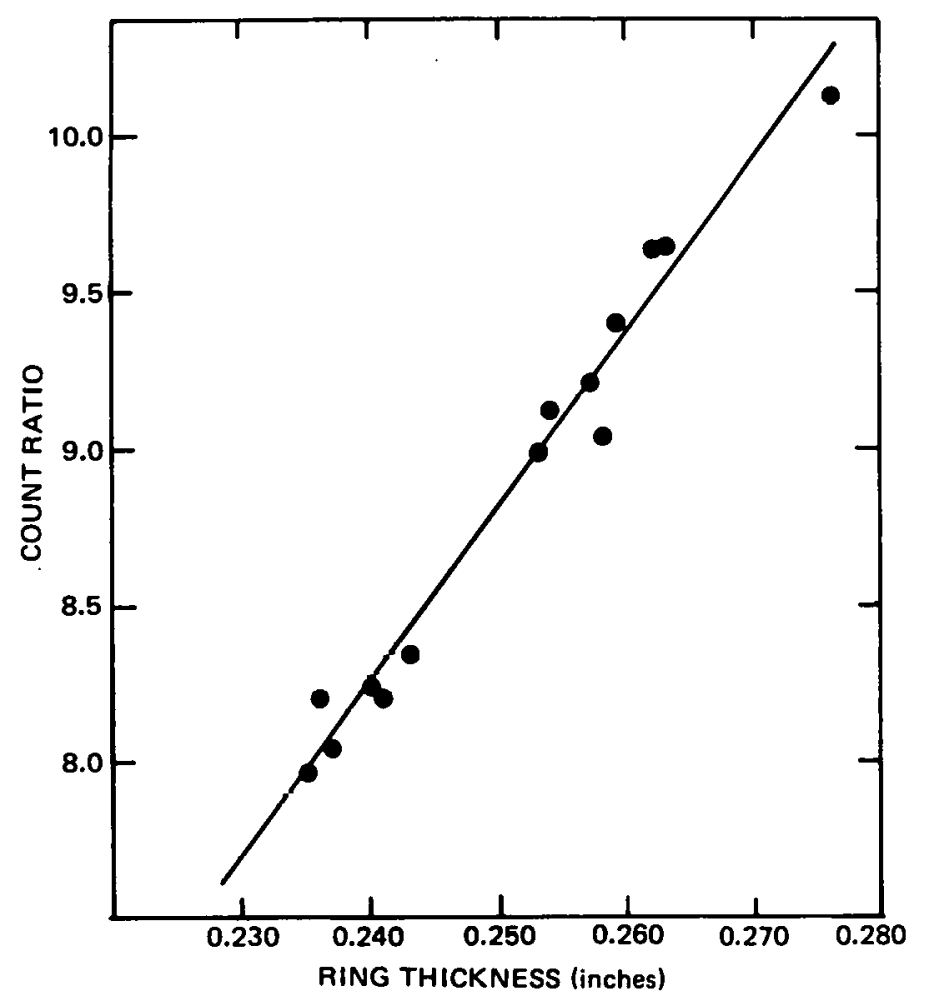

FIGURE 5. Linear Relationship Between

Count Ratio and Raschig Ring Thickness

Count Ratio Analysis

Random samples of fifty Raschig rings each were selected from the five standard lots $\mathrm{O}, \mathrm{P}, \mathrm{Q}, 129$, and 130 which had passed the required quality control criteria established by the Health, Safety, and Environmental Group. These 250 rings were carefully measured for thickness with a micrometer and then counted for neutron absorption. A source count in addition to a count of ring 5-12 were taken prior to each set of ten rings counted. At this point, three more standard lots $\mathrm{X}, \mathrm{Y}$, and $\mathrm{Z}$, declared acceptable according to established quality control requirements, became available for analysis. Samples of sizes 41,43 , and 47 from lots $X, Y$, and $Z$, respectively, were measured and counted. The mean thickness measurements and mean count ratios obtained for these eight lots are presented in Table 3. For the eight lots tested, the relative standard deviations of the mean count ratios were within the 1 to 5 percent range encountered on earlier lots.
TABLE 3. Mean Analysis Results on Entire Lots of Standard Raschig Rings

\begin{tabular}{ccc} 
Lot & Thickness (inches) & Mean Count Ratio \\
$\mathrm{O}$ & 0.259 & 9.32 \\
$\mathrm{P}$ & 0.259 & 9.26 \\
$\mathrm{Q}$ & 0.256 & 9.23 \\
129 & 0.241 & 8.29 \\
130 & 0.238 & 8.17 \\
$\mathrm{X}$ & 0.247 & 8.58 \\
$\mathrm{Y}$ & 0.247 & 8.61 \\
$\mathrm{Z}$ & 0.244 & 8.57 \\
\hline
\end{tabular}

These data were used to estimate the linear relationship, treating count ratio as the dependent variable and ring thickness as the independent variable. 'I he results of these calculations are: Slope $=55.141$, intercept $=4.969$, correlation coefficient $r=0.991$, mean thickness $=0.249$ inches, mean count ratio $=$ 8.754 , and the mean variance of the count ratio $\left(\hat{\sigma}^{2}\right)=0.00411$.

The statistical equation derived from these results for the prediction of a future count ratio at a fixed thickness is given as $\mathrm{CR}=-4.969+55.141 \cdot$ (Thickness), and the associated 95 percent prediction interval is:

$$
\pm 2.447(0.00411)^{1 / 2}\left[1+1 / 6+\frac{8(T-0.249)^{2}}{0.00374}\right]^{1 / 2}
$$

The statistical results for a range of thicknesses typical of Raschig:rings received at Rocky Flats are summarized in Table 4, and the resulting acceptance limits are depicted in Figure 6.

\section{Raschig Ring Evaluation}

As lots of Raschig rings arrive on plant site, the current quality control sampling plan makes available to the laboratory for evaluation 125 rings which are then distributed for the various tests. It is proposed that, in place of the current three determinations of $\mathrm{B}_{2} \mathrm{O}_{3}$ content and ${ }^{10} \mathrm{~B} /{ }^{11} \mathrm{~B}$ ratio, 50 rings be measured for thickness then neutron absorption counted. Background will be counted prior to each ten rings in the sample, and the count of ring 5-12 will serve as the control. The mean sample thickness will then be used to determine the 95 percent prediction interval from either Figure 6 
TABLE 4. Acceptable Count Ratios for Raschig Rings of Known Thickness

\begin{tabular}{|c|c|c|c|}
\hline \multirow{2}{*}{$\begin{array}{c}\text { Thickness } \\
\text { (inches) }\end{array}$} & \multirow{2}{*}{$\begin{array}{c}\text { Expected } \\
\text { Count Ratio } \\
\end{array}$} & \multicolumn{2}{|c|}{ Acceptable Limits } \\
\hline & & Lower & Upper \\
\hline 0.235 & 7.99 & 7.79 & 8.18 \\
\hline 0.240 & 8.26 & 8.09 & 8.44 \\
\hline 0.242 & 8.37 & 8.20 & 8.55 \\
\hline 0.244 & 8.48 & 8.31 & 8.65 \\
\hline 0.246 & 8.59 & 8.43 & 8.76 \\
\hline 0.248 & 8.70 & 8.54 & 8.87 \\
\hline 0.250 & 8.82 & 8.65 & 8.98 \\
\hline 0.252 & 8.93 & 8.76 & 9.09 \\
\hline 0.254 & 9.04 & 8.87 & 9.21 \\
\hline 0.256 & 9.15 & 8.97 & 9.32 \\
\hline 0.258 & 9.25 & 9.08 & 9.44 \\
\hline 0.260 & 9.37 & 9.18 & 9.55 \\
\hline 0.265 & 9.64 & 9.44 & 9.85 \\
\hline
\end{tabular}

or Table 4. If the mean sample count ratio falls within this interval, the lot will be declared acceptable. This test procedure will be computcrized and contain controls on both the counter and procedure. These controls will consist of checks on background and control ring 5-12 as well as sample variability. History files will be maintained so that the prediction intervals can be periodically reviewed and revised.

\section{SUMMARY AND CONCLUSIONS}

A neutron absorption counter has been designed and built to be used in the testing of Raschig rings for compliance to quality control specifications. One of the main functions of the Raschig ring is to absorb neutrons that could perpetuate a chain reaction. The main absorbing element in the rings is boron-10. Present standards insure proper neutron absorption characteristics of the rings by specifying $\mathrm{B}_{2} \mathrm{O}_{3}$ content and the ${ }^{10} \mathrm{~B} /{ }^{11} \mathrm{~B}$ ratio which indirectly specify boron- 10 content.

The technique described herein measures the neutron absorption directly. The basic measurement, neutron count ratio, is the ratio of the source count to a ring count. Experimental results indicate the $\mathrm{B}_{2} \mathrm{O}_{3}$ content. is linearly related to the neutron absorption ratios from this count. These data are included only to show that the relationship

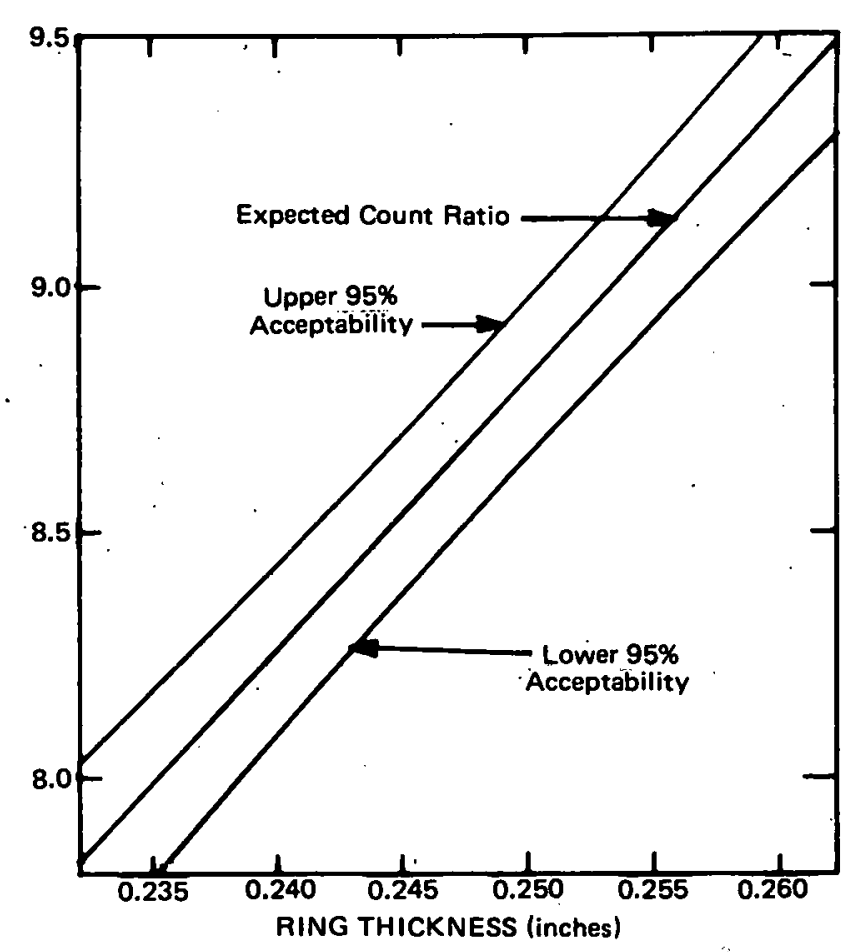

FIGURE 6. Count Ratio Acceptance Limits Versus Raschig Ring Thickness

exists and are not intended to define the parameters of the relationship.

Eight lots of standard Raschig rings were sampled and analyzed by present methods and found to meet all specifications. Random samples of about fifty rings from each lot were analyzed using the neutron absorption counter. 'These data were used to set acceptable limits in count ratio, adjusting for the wide variation in ring thickness encountered for rings arriving on plant site.

This investigation also indicates the variability encountered with present chemical analysis of Raschig rings for $\mathrm{B}_{2} \mathrm{O}_{3}$ content. Individual determinations of $\mathrm{B}_{2} \mathrm{O}_{3}$ in a given sample vary by greater than 10 percent relative to the mean result for some samples.

It is recommended that the neutron absorption counter be used as the primary test in place of the present $\mathrm{B}_{2} \mathrm{O}_{3}$ and ${ }^{10} \mathrm{~B} /{ }^{\mathbf{1 1}} \mathrm{B}$ tests. Since the quality control verification is presently based on the chemical tests, any lot that fails the neutron absorption test could be subjected to the chemical test for confirmation. The new method will save considerable testing time and laboratory costs as well as allow a greater number of rings to be tested. 
RFP-2787 